\title{
Islander migrations and the oceans: From hopes to fears?
}

\author{
Ilan Kelman \\ Institute for Global Health, University College London, UK \\ Institute for Risk and Disaster Reduction, University College London, UK \\ University of Agder, Kristiansand, Norway \\ ilan_kelman@hotmail.com
}

\section{Robert Stojanov \\ Faculty of Business and Economics, Mendel University in Brno, Czech Republic stojanov@centrum.cz}

\begin{abstract}
This paper explores islanders' hopes and fears for migration and non-migration, highlighting the role of the ocean. Migration, non-migration, hope, and fear are human conditions. To examine these conditions for islanders and oceans, this paper uses a qualitative evidence synthesis for collating and interpreting themes on the topic. Some types of hopes and fears, and a few reasons why they might emerge, are covered for islanders and oceanrelated migration. Then, different ocean representations which islander migration and nonmigration produces and portrays are presented. The conclusions question dichotomies and norms in the context of islander fears and hopes, as well as threats and opportunities, regarding ocean migrations.
\end{abstract}

Keywords: displacement, islands, island studies, migration, population dynamics, population movement, refugees

https://doi.org/10.24043/isj.120 • Received February 2020, accepted June 2020

(C) 2020 - Institute of Island Studies, University of Prince Edward Island, Canada.

\section{Introduction}

As has long been accepted by migration and mobilities studies, one human condition is and always has been movement and migration (Fiddian-Qasmiyeh et al., 2016; FiddianQasmiyeh, 2019; IOM, 2019; Jansen, 1970; Kunz, 1973; Petersen, 1958). We are all migrants, the title of Pieterse (2000), is a fair description of human beings, especially those near the oceans such as islanders. Many islanders have a long history of population movements, always having displayed continual migration, with people who move being an essential part of life in both the origin and destination locations (King, 2009; Lowenthal, 1985; Thomas-Hope, 1980). Reasons for migrating from islands are multi-faceted, ranging from health, education, adventure, and opportunity through to environmental and social changes (DeLoughrey, 2007; Hau'ofa, 2008). These reasons also apply to choices, or being forced, not to migrate; that is, staying on one's home island as non-migrants. 
This paper explores islanders' ocean-related hopes and fears with respect to migration and non-migration. The paper adopts a broad-brush, top-down perspective of the topic, considering a wide swathe of cases throughout human history and sources, including science across disciplines and fiction across formats, in order to extract and categorise ideas and viewpoints. Using the typology of Grant and Booth (2009), this methodology fits into a qualitative evidence synthesis, generating a narrative in the form of a critical review through selective and purposive sampling of material (as per an overview paper) to produce and criquitingly collate themes on the defined topic. The contribution to the literature emerges in exploring the fear-hope interchange for islander migrations and oceans.

Situating fear and hope briefly is necessary, given that they are not unique to islands or islanders but, like migration and non-migration, are human conditions. Nor are they only cultural or social constructs, since physiological indicators and responses are clearly documented (Lazarus, 1999 for hope; Maddox et al., 2019 for fear). Studies across disciplines examining hope and fear (e.g., He \& Zhou, 2013; Jarymowicz \& Bar-Tal, 2006; McManus, 2011) define them differently, but a useful concatenation might be that they are both emotions, with fear expressing concern about a threat and hope expressing desire for a positive outcome. For islander migrations, the focus here is thus on expressions and themes of concerns and desires about possible and actual outcomes related to the ocean.

\section{Oceans, islands, and migrations}

In many international policy discussions, migration used to be defined as being away from one's place of origin for at least a year, but this timeframe proved to be arbitrary and problematic, so it was phased out (UN, 1998). Now, a typical definition for a 'migrant' is " $\mathrm{A}$ person who moves away from his or her place of usual residence, whether within a country or across an international border, temporarily or permanently, and for a variety of reasons" (IOM, 2019, p. 130). A typical definition for 'migration' is “The movement of persons away from their place of usual residence, either across an international border or within a State" (IOM, 2019, p. 135). The International Organization for Migration (IOM) does not define 'non-migrant' or 'non-migration' (2019), although such a dichotomous approach to migration compared to non-migration or to immobility has its own limitations (Jónsson, 2011).

All forms of migration, non-migration, and immobility can have different degrees of being forced or voluntary, which is often a subjective judgement. If someone has resources and elects to move for adventure or fun, then such migration is certainly voluntary, also encompassing the debates on tourism as migration, even if temporary (e.g., O'Reilly, 2003). If soldiers proffer a choice of marching or being killed, or if land is expropriated for a shopping mall or a dam, then it would be hard to dispute the migration as being forced. Migration for a specific job, or for other economic rationales, is presumed to be voluntary, yet could also be considered as being forced if other viable options are effectively absent (Hugo, 1996).

Since migration and non-migration are not necessarily end states with a single influence, various outcomes can result, such as migrating several times to different locations, remaining in the destination yet being considered a migrant, and assimilating in the destination. Circular migration occurs when people leave for a time and then return, perhaps seasonally or with each stage taking several years (Guan \& McElroy, 2012; King \& Connell, 1999). Many islanders, such as in the Pacific (Hau'ofa, 2008) and the Caribbean (Chamberlain, 1998) 
developed their societies to include nomadic aspects (Baldacchino, 2007; DeLoughrey, 2007). If nomadism is accepted as being migration then, for these peoples, migration across the oceans is the norm, not the exception. It is not a one-off decision, but a continual, expected, and typical process. Non-migration is not the default, meaning that examining reasons for not migrating is as important as examining reasons for migrating.

Nonetheless, diminishing migration's exceptionality is not a justifiable excuse for forced migration. It simply places forced migration in wider contexts of mobilities. It is not about judging non-migration or migration, nor even setting up and maintaining this binary, but about recognizing that people deserve and want choices to pursue their own pathways, rather than losing control and choice, whether by expropriation, conflict, dictatorship, social changes, or environmental changes. The ocean has always played a role in such contexts, as a barrier inhibiting migration, as a pathway for migration, and, perhaps most of all, as an inspirer and dissuader in determining whether or not to set forth on, below, or above the waves to see what lies over, under, and above the horizon. The ocean attracts and repels movementparticularly for those for whom the ocean is typically present, such as islanders.

\section{Oceans of hope through migration}

Ever since humanity represented by Homo sapiens evolved into our contemporary species and moved out of Africa, possibly up to 200,000 years ago (Stringer \& Galway-Witham, 2018), today's world has been created, directed, and shaped by migration. From moving into unoccupied lands across the continents to traversing what are now ocean-linking water channels such as the Bering Strait and across Indonesia to Australia, migration has populated the world. More recently, including for islands, migration has been used for colonialism and oppression, such as transporting slaves to the Caribbean to take over Indigenous peoples' territories (Lewis, 2009) and evicting peoples from their lands and homes, such as the Chagossians when the UK and the US forced them to move from their Indian Ocean islands to make way for a military base (Evers \& Kooy, 2011).

Some great ocean voyages are speculative, for instance ancient trans-Atlantic and transPacific journeys, in either direction, by artefacts drifting and possibly by people (Callaghan, 2015; Jett, 2017). Long sea journeys which are known from past millennia typically involve islands and island hopping (Depraetere, 2008). Other than possibilities of Irish or other Celtic hermits, the first known settlers of the Faroe Islands and Iceland were Vikings whose sea travels included islands along the west coast of Norway, the islands around Scotland, and Kalaallit Nunaat (Greenland). Beforehand, successive waves of Indigenous peoples had arrived in Kalaallit Nunaat probably via island hopping across the Arctic islands of what is now Canada (Friesen et al., 2019).

Indian Ocean island hopping from Indonesia to Zanzibar, and using both land and water routes, has been happening for over two millennia (Brucato et al., 2017). Migration across and around the Indian Ocean helped cultures to spread including through island stopping points, such as Maldives, situated in the centre of historical trade routes between China, Arabia, and Africa (Colton, 1995). The first settlers to Maldives are believed to have moved there around 2,500 years ago, arriving from Gujarat (Bell, 1940). Since then, the ethnic mix comprising Maldivians today leads to the strongly identifiable genetic links between the mainland of South Asia and Maldives (Forbes, 1979; Pijpe et al., 2013). 
Pacific islanders are renowned for their lengthy voyages, building mini-villages on their boats for extended trips (Hau'ofa, 1993, 2008). About 3,000-4,000 years ago, after atolls started emerging from the Pacific Ocean following a peak in sea levels about two meters above the present day level, islanders continually found and settled these scattered, isolated islands (Dickinson, 2009). We will never know how many boats set off but did not find land, eventually succumbing to hunger and thirst or being toppled and wrecked by waves and storms. The animated movie Moana (Shurer et al., 2016) depicts an interesting possibility of a Pacific island society rejecting the ocean and ocean migration as part of their culture and livelihoods. Hope fades with declining food. The sentient sea then assists the principal character Moana to embark on an illicit ocean voyage to save her people and to reconnect them with their sea-borne heritage.

One principal driver of such movement across the Pacific was hope, aiming for new land, new lives, new opportunities, and new resources. In many cases, exiling, boredom, local resource destruction, and overcrowding cannot be ruled out, and were presumably part of the impetus for moving. Even so, hope of something better would form one basis for departing. This hope applies to both those leaving and those staying, with choice and lack of choice combining for both. Some would have been forced to join the trips, as slaves or as penance, through other duties and roles within their cultures, or being ordered because they had the perceived abilities and skills. Others would have wanted to leave but were prevented by duties and roles in their settlement, lack of perceived ability and skill to make the voyage and start a new home, or being criminals with exile not an option or not deemed to be just. Or perhaps they just wished to be at home, being a non-migrant even amongst migrant cultures.

Yet the hope of finding new land and developing a new society applies to those who stayed behind. They, too, placed their faith in the oceans of hope through not migrating and so gaining advantage from those who left. Local resource use would be reduced with fewer people and, if connections were maintained with the migrants, then trade and new resources might result, seen in modern times as remittances which are a mainstay of many islander communities from Cuba (Orozco \& Hansing, 2015) to the Marshall Islands (Picciotto, 2018). Meanwhile, if people were being exiled, then it rids the society of criminals-which might also make the criminals happy in terms of having a new start and leaving their past behind. Many convicts shipped from the UK to Australia were said to have been delighted at the opportunity to start anew (Elliott, 2019). While caution is always needed in accepting unconditionally a narrative which supports an oppressor, new opportunities in a new place should not be summarily dismissed as unwelcome. A similar situation is portrayed in Huxley's (1932) novel Brave New World in which the smartest people, who could not fit into the highly controlled society and were thus prone to social problems, were forced to move to an island of their choice. Many were happy and relieved to do so in order to be among people similar to themselves, rather than remaining outliers within the majority.

All forms of migrants and non-migrants gain advantage and hope through the use of the oceans as a migration route and separator of societies. The portrayal and reality of oceans of hope through migration integrates humanity into the surrounding seas, especially for the islander perspective of the ocean as part of life and society, rather than as a danger or separator (Hau'ofa, 1993). 


\section{Oceans of fear through migration}

Threats and dangers from the water are far from absent within islander cultures and mobilities. In Russell's (1996, p. 203) novel The Sparrow, Puerto Rican Felipe Reyes explains "Nothing like living on an island to convince you that land is the correct place to be." Healthy respect for the ocean's power and risks is far different from avoidance and disconnection, but it means that not all islanders are fishers or embrace coastal and maritime livelihoods.

Islander history is rife with migration-related threats coming over the ocean, namely through violent and non-violent invasion. Islanders such as on Iona, Scotland (Jones et al., 2020) lived in fear of Viking raids, while Norwegian islands and skerries were the sites of anti-Viking battles (Baug et al., 2019). Piracy and privateering (which are not synonymous, but which had comparable tactics and results) around Mediterranean islands was common in reality and was captured in literature between the sixteenth and nineteenth centuries (Klarer, 2018) as well as in the Caribbean during some similar time periods (Konstam, 2019; Woodward, 2008). It has also been documented for Japan in a slightly earlier age (Shapinsky, 2014). Invasions in more recent times which are not overtly violent, and which are frequently greeted joyfully by islanders, include tourism (Graci \& Dodds, 2010) and unhealthy food (Snowdon et al., 2010).

Contemporary discourse has turned the real and ubiquitous fatal threats from the sea, such as drowning and hypothermia, into a discourse of fear of the ocean and of islanders as migrants. Following the 2004 tsunami, many islanders in Sri Lanka and along Thailand's coastline were told that the tsunami inundation zone is too dangerous for living, so they had no choice but to resettle inland (Cohen, 2011; Khazai et al., 2006). This forced migration from the ocean (based on fear) divorces fishers from their coasts, thereby undermining their knowledge of the waves, currents, and weather which is essential to survival. Rather than seeking a balance, namely living by the sea with knowledge of tsunamis and storms alongside a functioning warning and evacuation system (Naylor et al., 2018), the ocean is assumed to be malfeasant only and so connections must be severed. As a contrast, both Bangladesh (including coastal and deltaic island communities; Haque et al., 2012; Mallick et al., 2011) and the island of Cuba (Aguirre, 2005; Sims \& Vogelmann, 2002) have had impressive successes with tropical cyclone warning and evacuation systems to avoid deaths by storm surge. For both countries, as was the case for the Indian Ocean islands before 26 December 2004, tsunami warnings and evacuations are far less tested, leaving people highly vulnerable, but the capability exists if it were implemented.

Some of the decisions to move coastal dwellers from tsunami-hit coastlines revealed a more insidious reasoning. In Sri Lanka and some Thai islands, poorer populations were denied permission to return to their properties on the premise that it was too dangerous to rebuild there, while the same rules were not applied to tourism owners and operators (Cohen, 2011; Khazai et al., 2006). Fear of the ocean was used to induce islander migration as a form of oppression and marginalization through land grabs, including for tourism-related profits which would end up mainly outside the country, as more recently illustrated aptly by Barbuda after Hurricane Irma in 2017 (Gould \& Lewis, 2018).

Fear of the ocean, and fear of forced migration due to the ocean, is used in current times in another powerful manner through assuming that many islanders will need to abandon their homes due to climate change, often termed 'climate migration' (or, incorrectly, 'climate 
refugees') or 'climate change migration' (or, incorrectly, 'climate change refugees'). The rationale is that climate change will cause sea levels to rise (with different mechanisms contributing to it), submerging coastlines and islands, so people must flee to higher ground. Yet wholescale destruction of islands is not inevitable. Dozens of islands, mainly in the Pacific, have been observed empirically for changes under measurable sea-level rise (e.g., Albert et al., 2016; Ballu et al., 2011; Kench et al., 2015; Rankey, 2011). Many islands are accreting horizontally or otherwise changing shape without loss of land, while others are diminishing in size, although some erosion is often attributed to local human action rather than to climate change (Biribo \& Woodroffe, 2013; Connell, 2016). Under ice sheet collapse, cities, islands, and coastlines would be likely to disappear underwater after the year 2100, leading to mass migration, although the impacts would extend through several centuries and some modelling suggests that low-lying islands might disappear only in highly extreme scenarios (Le Cozannet et al., 2018). Then, over millennia, influences start to be felt from the Earth's orbital cycles which significantly affect the planet's temperature (Dolan et al., 2011; Hays et al., 1976).

These nuances and uncertainties do not stop the instilling of fear regarding alleged waves of climate change refugees or climate change migrants coming across the oceans. Examples are Guzman (2013, p. 181) explaining about "refugee camps and cities overwhelmed with migrants fleeing climate change and its impacts" and the UK newspaper Independent's headline "Climate change could force more than a billion people to flee their homes" (Griffin, 2017). The latter was reporting on a paper stating:

climate change is the sole contributing factor for at least 4,400 people who are already being forced to migrate, worldwide. The total number of people vulnerable to migration might increase to 1 billion by the end of the century without significant further action on climate change. (Watts et al., 2018b, p. 593)

This one billion figure was caveated by $\pm 50 \%$. The causes of this migration focus on sea-level rise, but could potentially extend to heat waves and various mechanisms reducing freshwater supplies. Watts et al. (2018a, p. 2490) then revised those figures:

A lower bound of several thousand people are now migrating with climate change as the sole contributing factor. Future projections are highly uncertain because of challenges in projecting how society, technology, and politics will change over the coming decades. Nonetheless, in the absence of planning and interventions, several hundred million people could end up being vulnerable to forced migration, with climate change as the sole contributing factor.

Meanwhile, Bronen (2008, p. 31) aims to coin the term "climigration" which "occurs when a community is no longer sustainable exclusively because of climate-related events and permanent relocation is required to protect people."

Climate change is certainly inducing major impacts on the planet and on humanity; society is not adequately dealing with these shifts; and pathways to needed action are not being followed as much as required (IPCC, 2013-2014). If climate change impacts end up being worse than the median projections, or if severe and extreme changes appear, such as rapid ice sheet collapse, then islander migration due to climate change could be a dominant 
influence on their population dynamics - and coastal populations might be affected similarly. Denying any link between climate change and migration would be ignoring the reality which many locations must address involuntarily while downplaying scenarios which are realistic from now through to future decades and millennia.

Equally denying reality is focusing on climate change, especially for underlining a linear, causal connection from climate change to forced migration-which rarely exists. For instance, McNamara and Combes (2015) claim that climate change is causing the relocation of two coastal villages in Fiji, Narikoso and Vunidogoloa, but they do not provide any evidence for the climate change connections. Green (2016) explains how the coastline erosion observed by these villages might have been exacerbated by attempts to stop it, such as through a sea wall. Consequently, fearing the ocean and separating it artificially from the land such as through sea walls ends up creating the reality which confirms the fears and forces migration.

Furthermore, climate change poses a major ocean-related threat to many islands beyond sea-level rise inundating the land. More intense storms, higher oceans, and more powerful waves are contaminating freshwater sources (Karnauskas et al., 2016; Storlazzi et al., 2015). Without freshwater or alternatives, such as low-cost desalination which is not yet available everywhere, islanders might be forced to move from their homes due to climate change impacting freshwater resources with knock-on effects for food and ecosystems. Other mechanisms require further investigation, particularly coral reef survivability as one main example (Camp et al., 2018). If corals are unable to cope with higher ocean temperature and acidity due to climate change, then their protection of coastlines from waves and currents disappears and islands could erode more rapidly. Finally, the potentially biggest climate change related factor in islander migration is not ocean-related. In many areas around the world, heat waves exacerbated by climate change are expected to make it lethal to be outdoors for people, livestock, and crops (Watts et al., 2018a) meaning that the options are indoor temperature control $100 \%$ of the time, die, or move.

Even where significant climate change impacts are projected with the potential of forcing migration, such as in Maldives, populations are tending to emphasize the locally contextual gamut of reasons for moving. Rather than the ocean as a threat, these reasons include lack of living space, increasing land prices, low quality of services, and preference for better health and education access (Stojanov et al., 2017). This grounded viewpoint matches more detailed analyses, especially for islands, placing the interaction between climate change and migration into wider contexts of political discourses, power relations, and constructed narratives (e.g., Baldwin et al., 2019; Curtis \& Schneider, 2011; Oakes, 2019; Perumal, 2018; Schwebel, 2018).

Although ocean-related hazards from tsunamis to storms to climate change bring legitimate caution and concern, they are being used to terrify, so that forced islander migration seems to be the only option. The notion of the ocean as a killer-even where well-founded throughout history-ensures that fearful fleeing from the ocean is prioritized, yielding terror in terms of unwanted migrants allegedly forcing their way into ostensibly innocent countries and homes. The xenophobic viewpoints of migrants as being dangerous and of migration being detrimental to a destination has dominated recent politics around the world (Andersson, 2019), even when compiled evidence illustrates the opposite (Abubakar et al., 2018). As such, migration-related fear is generated in the origin and destination locations. 


\section{Ocean representations for islander migration}

The fears of islanders and of possible migration destinations about climate change devastating island countries leading to mass migration have led to numerous, incorrect representations of islander migration across oceans. Adger and Barnett (2005, p. 328) described "New Zealand's creation of the Pacific Access Category, in response to concerns about climate change" without providing any evidence of links to or consideration of climate change. As the Pacific Access Category's information evolved, it continued to frame the program as permitting a cohort of skilled and healthy citizens from a few Pacific countries to settle in New Zealand, provided they had a job offer. Environmental or climate reasons have not been mentioned in the official documentation or information.

Nevertheless, a handful of cases of Pacific islanders in New Zealand aiming to claim climate change refugee status have emerged. These cases have thus far been declined (e.g., Burson, 2013) even where the claimants were permitted to remain in New Zealand for other reasons (e.g., Burson, 2014). In December 2017, New Zealand indicated the possibility of creating a new category of visas specifically covering climate change refugees, although it would apply to perhaps a hundred people from Pacific island countries per year. The proposal was later withdrawn. Currently, no countries have a specific climate-related visa for forced migrants, but legal and political regimes are evolving in order to develop climate change migration as an official category, without entirely embracing scientific conclusions from across climate change, migration, and mobilities research.

To support this work, lessons emerge from other examples of islander migration linked to environmental changes. Volcanic eruptions have been involved in dozens of sudden, forced migrations over past decades, incorporating numerous instances when return was not expected to be an option or was assumed not to be an option. From islands, examples are Niuafo'ou in Tonga in 1946 (Lewis, 1979), Vestmannaeyjar in Iceland in 1973 (Chester, 1993), and Montserrat after 1995 (Pattullo, 2000). Similarly, island communities from Kalaallit Nunaat (Dugmore et al., 2007) to the Pacific (Nunn \& Carson, 2015) display long histories of abandoning communities, possibly through a combination of mass migration and dying out, with one factor amongst many suggested as being climatic shifts. These analogies could assist in contemporary forecasting and planning of islander movement for related and other reasons (Glantz, 1988).

Many descriptions highlighted in current public discourse are often about representing fears which supersede hopes. Cubans and Haitians have long made the voyage over the sea to the USA and, at times, Bahamas, for the presumptions of a better quality of life, more lucrative livelihoods, and the opportunity to send back remittances (Loyd \& Mountz, 2018; Mainwaring \& Cook, 2019). Comorians seeking France's territory of Mayotte, now an overseas department, have done similarly (Blanchy, 2018). In these cases, hopes remain that life will be better as a migrant across the ocean in the better-off location, while being able to make life better for those left behind. Yet much of the media and populist framing is about the islanders being driven by fears of conditions in their homes, including political oppression, violence, poverty, and marginalization (Lohmeier, 2014). Without denying these real and legitimate fears which are an impetus, more work is needed to seek the islander migrants' views of how they balance fears and hopes in their decisions to risk their lives on the ocean and in their destinations. In the meantime, fears in destination locations might then transcend 
into (unjustified) fears of the migrants who are presumed to bring crime and disease or to take over the destination's culture and values.

Migration research traditionally separated mobility drivers into push factors and pull factors, but then recognized the interlinkages, overlaps, and inadequacies of this binary. Consequently, a strong agenda remains to investigate more deeply and thoroughly how migrants view their migration through the push-and-pull lenses, especially the balance of negatively connoted emotions such as fear and positively connoted emotions such as hope. The tension and synergies between different representations of the ocean as a pathway for migration certainly play out in island cultures. The Barbadian poet Frank Collymore starts Hymn to the Sea (1959, p. 48) with the lines, "Like all who live on small islands, / I must always be remembering the sea." He then goes on to feminize the sea, followed by sexualizing it, and then viewing it as a mother. The portrayals are generally of positive experiences, although the poem ends with references to storms and death, not necessarily as negative, but certainly with undercurrents of trepidation and anxiety.

A different progression is seen in the classic island voyage novel The Voyage of the Dawn Treader (Lewis, 1952), the fifth in the Narnia series. During the voyage of discovery for seven missing Narnian lords, matching the voyage of personal character discovery for the three English children on board the ship, the islands they encounter traverse hopes, fears, hopes transformed into fears, fears transformed into hopes, and the combinations of hopes and fears. Reepicheep the mouse becomes the ultimate migrant full of hope by voluntarily entering Aslan's land.

Other representations combining islander migration hopes and fears appear in the form of 'Fishermen's wives memorials', such as around the North Sea. Traditionally, most fishers were men going out onto the sea for hours or days in a form of circular migration for livelihoods. Their wives would tend the home, awaiting their return. Given the propensity for storms, high waves, rocks, and other shipwrecking phenomena, many boats never arrived back, leaving their wives, families, and communities to make the decision when to assume that the fishers were lost forever. As with the disaster memorial at Gloup in the north of the island of Yell, Shetland, Scotland, a statue shows a fisherman's wife holding their child, looking forever out to sea in the hope that her husband will appear on the horizon with the fear that he never will. Gloup's memorial was erected for the 20 July 1881 storm which killed 58 fishermen from the small community. The ocean, and migration around it, brings life through fishing livelihoods alongside sudden death. And this balance is fully accepted, according to the narrative that some of the fishers refuse to learn how to swim with the premise that, if the boat sinks, why prolong the agony?

Despite the general pattern of representations of oceans and islander migration, fictional and real, not all conform. The town of Sete Cidades, São Miguel, Azores, Portugal tells a useful tale. The town sits entirely inside a volcano's caldera, more than 300 meters below the caldera's rim and just a few kilometers from the Atlantic Ocean. The story, possibly apocryphal and certainly poetic, is that even up to the 1990s, some residents of Sete Cidades, numbering several hundred, had never left the caldera. Despite living on a small island in the middle of the ocean, these people would never have seen the sea, so migration beyond the confines of their town, even temporarily, was not part of their worldview.

As another example of not migrating, even Maldivians who recognize the possible impacts of sea-level rise and other changes express reticence to depart their country (Stojanov 
et al., 2017). They do not want to lose their roots and traditions related to family, culture, friends, land, language, and religion, especially when they still enjoy living in the current island environment. For them, loss of identity and familiarity is a far bigger risk than the ocean encroaching onto their land.

\section{Multi-dimensional islander migration through the oceans}

The diversity of migrants and non-migrants amongst human populations, and the diversity of reasons for migrating and for not migrating, have long been published (Jansen, 1970; Kunz, 1973; Petersen, 1958). While recognizing how migration and mobilities theories have evolved, with discussions becoming less prejudiced and more introspective over the decades (e.g., Fiddian-Qasmiyeh et al., 2016; Fiddian-Qasmiyeh, 2019), this rich literature yields important lessons for investigating the ocean's place in islander migration.

One challenge has always been defining "migration". What is the distance which someone must move in order to be termed a migrant? Within an atoll, if someone moves a hundred meters from one island to another or ten meters from one side of an island to the other side, are they both equivalent migration? For some islands, moving ten meters could mean leaving the expected floodplain under climate change for several decades into the future. Pingelap is an atoll within the Federated States of Micronesia. Some parts of the atoll rise above 15 meters above sea level, but all the atoll's land sits within 300 meters of the ocean. In theory, the people could redesign and rebuild their community on the higher parts of their atoll to avoid impacts from sea-level rise, meaning that no one would move very far (presuming that freshwater would still be available and that heat would not preclude habitability). Alternatively, migration to and from the atoll has always been presumed to be part of Pingelap's population dynamics (Morton et al., 1971), so out-migration could be enhanced rather than being entirely new.

In any case, for those who wish to remain on the atoll, amphibious approaches could be considered. Some nomadic islanders live in boats, such as throughout Burma's Mergui Archipelago (Stacey \& Allison, 2019), leading to possibilities for other cultures to adopt a boat-based, ocean-going lifestyle. Others have postulated island cities and states floating on the oceans and roaming the world, including examining the legal, social, and technical aspects (Bolonkin, 2011). Ever-moving island civilizations are depicted in fiction, such as the movie Waterworld (Herzberg et al., 1995) and the novel Flood (Baxter, 2008).

If islanders wish to remain fixed in one place no matter how coastlines are changing, then buildings could be raised or ground floors could be opened up to permit water flow with other storeys placed on top. People would live in the same island location as before, perhaps now in the tidal zone, although they would be migrating upwards. Vertical migration to live much more with the ocean is a possibility for islanders, not just to deal with sea-level rise and shifting shores, but also to expand into current lagoons in order to increase the living space available. This approach has been enacted for luxury tourism, with one Maldivian resort having built walkways from a private island into the sea to reach villas on stilts for US\$1,100+ per night in the low season.

Rather than constructing just a villa or a house in order to migrate into the sea, entire islands have been built to support islander movement. Hong Kong's airport was constructed on the largely artificial island of Chek Lap Kok to facilitate international travel to and from 
the island city (Pickles \& Tosen, 1998). Between 2001 and 2011, Dubai aimed to build the Palm Islands and the World Islands into the Persian Gulf, to add significant lengths of beaches and significant numbers of luxury properties (Gupta, 2015). Maldives has substantially increased its land area through reclamation, with the island of Hulhumale built to ease pressure on living space in the capital Malé (Malatesta \& Schmidt di Friedberg, 2017) along with Hulhulé for the international airport. These instances support permanent migration to land which was once ocean and have had major marine impacts, influencing nearby marine ecosystems and creating new coastal and tidal ones.

In addition to migrating vertically upwards on an island and horizontally out from an island, consideration could be given to migrating vertically downwards into the ocean, by constructing underwater settlements. Under-ocean cities have appeared in the scientific literature (Kaji-o'grady \& Raisbeck, 2005; Riffat et al., 2016) and in fiction including the planet Naboo's undersea city Otoh Gunga in Star Wars: Episode I - The Phantom Menace (Lucas, 1999). It is the same with cities in the sky, hovering in a planet's atmosphere and either fixed or floating, speculated in science (Riffat et al., 2016) and presented in fiction, such as Laputa (Swift, 1726) and again from Star Wars, this time Star Wars: Episode V-The Empire Strikes Back (Lucas \& Kershner, 1980) with Cloud City on the planet Bespin.

This multi-dimensional migration through the oceans is based on the assumption of water being the medium considered, which is the case for Planet Earth. As humanity dreams of colonizing the solar system, and perhaps beyond, other seas await. In March 2019, the US government announced the Artemis program designed to return Americans to the Moon by 2024 (https://www.nasa.gov/specials/artemis). Numerous places on the Moon are named as seas, including the Sea of Tranquillity where the first landing occurred in 1969, but they are dry. Same with Mars, leading the trilogy of Red Mars (Robinson, 1993), Green Mars (Robinson, 1994), and Blue Mars (Robinson, 1996) to explain how the planet might be terraformed-or, as the author writes, areoformed with "areo" from the Greek god Ares meaning Mars-to produce water-filled oceans.

Farther afield, the dynamic surface of Jupiter's moon Io could be described as having oceans of molten rock (Lopes \& Spencer, 2007) while Saturn's moon Titan has been discussed as having oceans of ethane and methane (Flasar, 1983; Lunine et al., 1983). If human beings were able to migrate to these oceans and construct settlements, as described in the Bio of a Space Tyrant series (Anthony, 1983-1986 with an extra book in 2001), would the moons themselves or the settlements be the islands? Some would dispute the moniker "island" given that they are not linked to water. The three other Galilean moons of Jupiter-Callisto, Europa, and Ganymede-have frozen water on their surfaces and could have liquid water oceans below their surfaces (Heggy et al., 2017). Prospects exist for immersed settlements, fixed or mobile, becoming islands.

Oceans of islander migration therefore embrace multiple meanings, beyond water and beyond the Earth. They return to the hope of lengthy, strange, dangerous migrationexperienced by the Vikings and the Pacific islanders, amongst others, when they set forth in their surface crafts to see what might lie across the vast water-for seeking fun, adventure, resources, and newness. They provide opportunities to overcome current fears and knowledge of overpopulation, overconsumption, and toxic overload plaguing the only inhabited planet known to humanity. They introduce new fears, such as those related by Ben Elton in his 
novel Stark (Elton, 1989), that migration across the oceans of space's vacuum to the islands of planets and moons will be achieved primarily to escape a fatally contaminated Earth.

\section{Conclusion}

This paper has highlighted oceans of hope and fear regarding islanders migrating and not migrating, particularly their relationship to the ocean. In doing so, aspects of islander norms (as far as islander norms exist) are reaffirmed (see also Grydehøj, 2020) in that the sea and connections to it can be far more the norm than the land, while migration can be far more the norm than sedentariness (see also Hau'ofa, 1993, 2008). These situations are not always the case, as amply demonstrated by the COVID-19 pandemic of 2020 severely curtailing domestic and international migration, with numerous island locations closing their borders entirely. Nonetheless, ocean-migration links are frequently a basis for many islander hopes, especially with respect to livelihoods and futures.

Interlaced with these hopes are fears. Fear of death is real when crossing large bodies of water, as is fear that the destination might not work out. Fear of migrants and new arrivals in a location have also been present in potential destinations, driven in contemporary times by political and media constructions of migrants and migration as threats. A balance of hope and fear is healthy, and has long been the norm. An imbalance in either direction can create challenges, when fear becomes hostility or hope means ignoring real danger.

These explorations reinforce a baseline regarding the lack of dichotomies and binaries in the pairs presented above. Since hope and fear are intertwined, they are not extremes at opposite ends of a continuum. They are necessary, ever-present, much-needed phenomena which can and should exist side-by-side to balance hope inducing courage for fulfilling the desire for new territories and opportunities with trepidation inducing a modicum of caution towards actual and potential threats.

Migration and non-migration, immobility, and sedentariness are interwoven, with the latter three not necessarily being the same and not necessarily being the opposite of migration. It is the same for land and ocean not being opposites or separated-a motif often employed in fiction about the island of Atlantis, such as the movie Aquaman (Berg et al., 2018). The ocean and land overlap through tidal zones - on daily, monthly, seasonal, and decadal cyclesand through dynamic (migrating) coasts involving erosion, accretion, and infiltration. At times, the zone of overlap expands, such as runoff from land to the sea impacting marine ecosystems while ocean-originating hazards can inundate typically dry land through storm surge, tsunamis, tidal waves, and tidal bores.

Consequently, for islanders and island societies, oceans and migration are not exceptions: ocean, land, migration, non-migration, hope, and fear are all about acknowledging the norm of what it means to be an islander. As sung in the opening number of the musical Come From Away about being an islander from Newfoundland, "Welcome to the land where the waters try to drown us and we said, "we will not be drowned"" (Sankoff \& Hein, 2013, pp. 4-5). The water and the ocean, through their contributions to migration and non-migration, provide opportunities and threats, but threats within the opportunities and opportunities within the threats. 


\section{Acknowledgements}

This paper was completed as part of the Lancet Countdown project (Tracking the connections between public health and climate change) at http://www.lancetcountdown.org. The Lancet Countdown's work is supported by an unrestricted grant from the Wellcome Trust (200890/Z/16/Z).

\section{References}

Abubakar, I., Aldridge, R.W., Devakumar, D., Orcutt, M., Burns, R., Barreto, M.L., Dhavan, P., Fouad, F.M., Groce, N., Guo, Y., Hargreaves, S., Knipper, M., et al. (2018). The UCL-Lancet Commission on Migration and Health: The health of a world on the move. The Lancet, 392(10164), 2606-2654. https://doi.org/10.1016/s0140$\underline{6736(18) 32114-7}$

Adger, W.N., \& Barnett, J. (2005). Compensation for climate change must meet needs. Nature, 436, 328. https://doi.org/10.1038/436328c

Aguirre, B.E. (2005). Cuba's disaster management model: Should it be emulated? International Journal of Mass Emergencies and Disasters, 23(3), 55-71.

Albert, S., Leon, J.X., Grinham, A.R., Church, J.A., Gibbes, B.R., \& Woodroffe, C.D. (2016). Interactions between sea-level rise and wave exposure on reef island dynamics in the Solomon Islands. Environmental Research Letters, 11, 054011. https://doi.org/10.1088/1748-9326/11/5/054011

Andersson, R. (2019). No go world: How fear is redrawing our maps and infecting our politics. Oakland: University of California Press. https://doi.org/10.1111/aman.13393

Anthony, P. (1983-1986). Bio of a Space Tyrant. New York: Avon.

Baldacchino, G. (2007). History and identity across small islands: A Caribbean and a personal journey. Miscellanea Geographica, 17(2), 5-11. https://doi.org/10.1111/aman.13393

Baldwin, A., Christiane F., \& Rothe, D. (2019). From climate migration to Anthropocene mobilities: Shifting the debate. Mobilities, 14(3), 289-297. https://doi.org/10.1080/17450101.2019.1620510

Ballu, V., Bouin, M.-N., Siméoni, P., Crawford, W.C., Calmant, S., Boré, J.-M., Kanas, T., \& Pelletier, B. (2011). Comparing the role of absolute sea-level rise and vertical tectonic motions in coastal flooding, Torres Islands (Vanuatu). PNAS, Proceedings of the National Academy of Sciences, 108, 13019-13022. https://doi.org/10.1073/pnas.1102842108

Baug, I., Skre, D., Heldal, T., \& Jansen, Ø.J. (2019). The Beginning of the Viking Age in the West. Journal of Maritime Archaeology, 14, 43-80. https://doi.org/10.1007/s11457$\underline{018-9221-3}$

Baxter, S. (2008). Flood. London: Gollancz.

Bell, H.C.P. (1940). The Maldive Islands. Monograph on the history, archeology and epigraphy. Colombo: Ceylon Government Press.

Berg, J. (Executive Producer), Hamada, W. (Executive Producer), Johns, G. (Executive Producer), Snyder, D. (Executive Producer), Snyder, Z. (Executive Producer), \& Wan, J. (Director). (2018). Aquaman [Motion Picture]. USA: DC Comics, DC Entertainment, Panoramic Pictures, Rodeo FX, The Safran Company, \& Warner Bros. 
Biribo, N., \& Woodroffe, C.D. (2013). Historical area and shoreline change of reef islands around Tarawa Atoll, Kiribati. Sustainability Science, 8, 345-362. https://doi.org/10.1007/s11625-013-0210-z

Blanchy, S. (2018). Families and the new local civil law in Mayotte: The continuity, adaptation, and redefinition of practices. Ethnologie française, 1(169), 47-56. https://doi.org/10.3917/ethn.181.0047

Bolonkin, A.A. (2011). Floating cities. In S.D. Brunn (Ed.), Engineering earth: The impacts of megaengineering projects (Vol. 1, pp. 967-983). Dordrecht: Springer.

Bronen, R. (2008). Alaskan communities' rights and resilience. Forced Migration Review, 31, 30-32.

Brucato, N., Kusuma, P., Beaujard, P., Sudoyo, H., Cox, M.P., \& Ricaut, F.-X. (2017). Genomic admixture tracks pulses of economic activity over 2,000 years in the Indian Ocean trading network. Scientific Reports, 7, 2919. https://doi.org/10.1038/s41598017-03204-y

Burson, B.L. (2014). NZIPT 501370-371. Auckland: Immigration and Protection Tribunal. Burson, B.L. (2013). NZIPT 800413. Auckland: Immigration and Protection Tribunal.

Callaghan, R.T. (2015). Drift voyages across the mid-Atlantic. Antiquity, 89(345), 724-731. https://doi.org/10.15184/aqy.2015.25

Camp, E.F., Schoepf, V., \& Suggett, D.J. (2018). How can 'Super Corals' facilitate global coral reef survival under rapid environmental and climatic change? Global Change Biology, 24(7), 2755-2757. https://doi.org/10.1111/gcb.14153

Chamberlain, M. (1998). Caribbean migration: Globalized identities. London: Routledge.

Chester, D.K. (1993). Volcanoes and society. London: Edward Arnold.

Cohen, E. (2011). Tourism and land grab in the aftermath of the Indian Ocean tsunami. Scandinavian Journal of Hospitality and Tourism, 11(3), 224-236. https://doi.org/10.1080/15022250.2011.593359

Collymore, F. (1959). Collected poems. Bridgetown: Advocate.

Colton, E.O. (1995). The elite of the Maldives: Sociopolitical organisation and change [Unpublished doctoral dissertation]. London School of Economics and Political Science.

Connell, J. (2016). Last days in the Carteret Islands? Climate change, livelihoods and migration on coral atolls. Asia Pacific Viewpoint, 57, 3-15. https://doi.org/10.1111/apv.12118

Curtis, K.J., \& Schneider, A. (2011). Understanding the demographic implications of climate change: Estimates of localized population predictions under future scenarios of sea-level rise. Population and Environment, 26(1), 28-54. https://doi.org/10.1007/s11111-011$\underline{0136-2}$

DeLoughrey, E.M. (2007). Routes and roots: Navigating Caribbean and Pacific island literatures. Honolulu: University of Hawai'i Press. https://doi.org/10.1515/9780824864187

Depraetere, C. (2008). The challenge of nissology: A global outlook on the world archipelago - Part I: Scene setting the world archipelago. Island Studies Journal, 3(1) 3-16.

Dickinson, W.R. (2009). Pacific atoll living: How long already and until when? GSA Today 19(3), 4-10. https://doi.org/10.1130/gsatg35a.1

Dolan, A.M., Haywood, A.M., Hill, D.J., Dowsett, H.J., Hunter, S.J., Lunt, D.J., \& Pickering, S.J. (2011). Sensitivity of Pliocene ice sheets to orbital forcing. 
Palaeogeography, Palaeoclimatology, Palaeoecology, 309, 98-110. https://doi.org/10.1016/j.palaeo.2011.03.030

Dugmore, A.J., Keller, C., \& McGovern, T.H. (2007). Norse Greenland settlement: Reflections on climate change, trade, and the contrasting fates of human settlements in the North Atlantic islands. Arctic Anthropology, 44, 12-36. https://doi.org/10.1353/arc.2011.0038

Elliott, D.W. (2019). Transported to Botany Bay: Class, national identity, and the literary figure of the Australian convict. Athens, OH: Ohio University Press.

Elton, B. (1989). Stark. London: Sphere.

Evers, S., \& Kooy, M. (Eds.). (2011). Eviction from the Chagos Islands: Displacement and struggle for identity against two world powers. Leiden: Brill. https://doi.org/10.1163/ej.9789004202603.i-293

Fiddian-Qasmiyeh, E. (Ed.). (2019). Refuge in a moving world: Interdisciplinary conversations. London: UCL Press.

Fiddian-Qasmiyeh, E., Loescher, G., Long, K., \& Sigona, N. (Eds.). (2016). The Oxford handbook of refugee and forced migration studies. Oxford: Oxford University Press. https://doi.org/10.1093/oxfordhb/9780199652433.013.0010

Flasar, F.M. (1983). Oceans on Titan? Science, 221(4605), 55-57. https://doi.org/10.1126/science.221.4605.55

Forbes, A.D.W. (1979). The mosque in the Maldive Islands: A preliminary historical survey. Archeologie Musulmane, 26, 43-74. https://doi.org/10.3406/arch.1983.1844

Friesen, T.M., Finkelstein, S.A., \& Medeiros, A.S. (2019). Climate variability of the Common Era (AD 1-2000) in the eastern North American Arctic: Impacts on human migrations. Quaternary International. Epub ahead of print. https://doi.org/10.1016/j.quaint.2019.06.002

Glantz, M.H. (1988). Societal responses to regional climatic change: Forecasting by analogy. Boulder: Westview.

Gould, K.A., \& Lewis, T.L. (2018). Green gentrification and disaster capitalism in Barbuda: Barbuda has long exemplified an alternative to mainstream tourist development in the Caribbean. After Irma and Maria, that could change. NACLA Report on the Americas, 50(2), 148-153. https://doi.org/10.1080/10714839.2018.1479466

Graci, S., \& Dodds, R. (2010). Sustainable tourism in island destinations. London: Earthscan.

Grant, M.J., \& Booth, A. (2009). A typology of reviews: An analysis of 14 review types and associated methodologies. Health Information and Libraries Journal, 26(2), 91-108. https://doi.org/10.1111/j.1471-1842.2009.00848.x

Green, M. (2016). Contested territory. Nature Climate Change, 6, 817-820.

Griffin, A. (2017, October 31). Climate change could force more than a billion people to flee their homes, says major health report. The Independent (UK). Retrieved from http://www.independent.co.uk/news/science/climate-change-global-warmingrefugees-migrants-displacement-lancet-study-a8028341.html

Grydehøj, A. (2020). Critical approaches to island geography. Area, 52(1), 2-5. https://doi.org/10.1111/area.12546

Guan, J., \& McElroy, J. L. (2012). The determinants of migration in small islands. Shima, 7(1), 80-95. 
Gupta, P. (2015). Futures, fakes and discourses of the gigantic and miniature in 'The World' islands, Dubai. Island Studies Journal, 10(2), 181-196.

Guzman, A.T. (2013). Overheated: The human cost of climate change. Oxford: Oxford University Press.

Haque, U., Hashizume, M., Kolivras, K.N., Overgaard, H.J., Das, B., \& Yamamoto, T. (2012). Reduced death rates from cyclones in Bangladesh: What more needs to be done? Bulletin of the World Health Organization, 90(2), 150-156. https://doi.org/10.2471/blt.11.088302

Hau'ofa, E. (2008). We are the ocean. Honolulu: University of Hawai'i Press.

Hau'ofa, E. (1993). A new Oceania: Rediscovering our sea of islands. Suva: University of the South Pacific.

Hays, J.D., Imbrie, J., \& Shackleton, N.J. (1976). Variations in the Earth's orbit: Pacemaker of the Ice Ages. Science, 194(4270), 1121-1132. https://doi.org/10.1126/science.194.4270.1121

He, X.D., \& Zhou, X.Y. (2013). Hope, fear, and aspirations. Mathematical Finance, 26(1), 350. https://doi.org/10.1111/mafi.12044

Heggy, E., Scabbia, G., Bruzzone, L., \& Pappalardo, R.T. (2017). Radar probing of Jovian icy moons: Understanding subsurface water and structure detectability in the JUICE and Europa missions. Icarus, 285, 237-251. https://doi.org/10.1016/j.icarus.2016.11.039

Herzberg, I. (Executive Producer), Licht, A. (Executive Producer), Mueller, J. (Executive Producer), \& Reynolds, K. (Director). (1995). Waterworld [Motion Picture]. USA: Universal Pictures.

Hugo, G. (1996). Environmental concerns and international migration. International Migration Review, 30(1), 105-131. https://doi.org/10.2307/2547462

Huxley, A. (1932). Brave New World. London: Chatto \& Windus.

IOM. (2019). Glossary on migration. Geneva: International Organization for Migration (UN Migration).

IPCC. (2013-2014). Fifth assessment report. Geneva: Intergovernmental Panel on Climate Change (IPCC).

Jansen, C.J. (1970). Migration: A sociological problem. In C.J. Jansen (Ed.), Readings in the sociology of migration (pp. 3-35). Oxford: Pergamon. https://doi.org/10.1016/b978-008-006915-9.50006-1

Jarymowicz, M., \& Bar-Tal, D. (2006). The dominance of fear over hope in the life of individuals and collectives. European Journal of Social Psychology, 36(3), 367-392. https://doi.org/10.1002/ejsp.302

Jett, S.C. (2017). Ancient ocean crossings: Reconsidering the case for contacts with the pre-Columbian Americas. Tuscaloosa: University of Alabama Press. https://doi.org/10.14237/ebl.9.2.2018.1352

Jones, S.E., Allison, E.P., Campbell, E., Evans, N., Mighall, T., \& Noble, G. (2020). Identifying social transformations and crisis during the pre-Monastic to post-Viking era on Iona: New insights from a palynological and palaeoentomological perspective. Environmental Archaeology. Epub ahead of print. https://doi.org/10.1080/14614103.2020.1713581 
Jónsson, G. (2011). Non-migrant, sedentary, immobile, or 'left behind'? Reflections on the absence of migration. Oxford: International Migration Institute.

Kaji-o'grady, S., \& Raisbeck, P. (2005). Prototype cities in the sea. The Journal of Architecture, 10(4), 443-461. https://doi.org/10.1080/13602360500285641

Karnauskas, K.B., Donnelly, J.P., \& Anchukaitis, K.J. (2016). Future freshwater stress for island populations. Nature Climate Change, 6, 720-725. https://doi.org/10.1038/nclimate2987

Kench, P.S., Thompson, D., Ford, M.R., Ogawa, H., \& McLean, R.F. (2015). Coral islands defy sea-level rise over the past century: Records from a central Pacific atoll. Geology, 43, 515-518. https://doi.org/10.1130/g36555.1

Khazai, B., Franco, G., Ingram, J.C., del Rio, C.R., Dias, P., Dissanayake, R., Chandratilake, R., \& Kanna, S.J. (2006). Post-December 2004 tsunami reconstruction in Sri Lanka and its potential impacts on future vulnerability. Earthquake Spectra, 22(S3), S829-S844. https://doi.org/10.1193/1.2204925

King, R. (2009). Geography, islands and migration in an era of global mobility. Island Studies Journal, 4(1), 53-84.

King, R., \& Connell, J. (Eds.). (1999). Small worlds, global lives: Islands and migration. London: Pinter.

Klarer, M. (Ed.). (2018). Piracy and captivity in the Mediterranean: 1550-1810. Abingdon: Routledge.

Konstam, A. (2019). The pirate world: A history of the most notorious sea Robbers. Oxford: Bloomsbury.

Kunz, E.F. (1973). The refugee in flight: Kinetic models and forms of displacement. International Migration Review, 7, 124-146. https://doi.org/10.2307/3002424

Lazarus, R.S. (1999). Hope: An emotion and a vital coping resource against despair. Social Research, 66(2), 653-678.

Le Cozannet, G., Duvat, V., Salvat, B., Etienne, S., Terorotua, H., Garcin, M., Lecacheux, S., \& Montaggioni, L. (2018). Modelling the response of atoll reef islands to multimillennial sea level rise from the Last Glacial Maximum to the coming 10kyr: The case of Mururoa Atoll (Tuamotu, French Polynesia). Journal of Coastal Research, SI 85, 511 515. https://doi.org/10.2112/si85-103.1

Lewis, C.S. (1952). The Voyage of the Dawn Treader. London: Geoffrey Bles.

Lewis, J. (2009). An island characteristic: Derivative vulnerabilities to indigenous and exogenous hazards. Shima, 3(1), 3-15.

Lewis, J. (1979). Volcano in Tonga. Journal of the Administration Overseas, XVIII(2), 116-121. Lohmeier, C. (2014). Cuban Americans and the Miami media. Jefferson: McFarland \& Company. Lopes, R.M.C., \& Spencer, J.R. (2007). Io after Galileo: A new view of Jupiter's volcanic moon. Berlin: Springer.

Lowenthal, D. (1985). Mobility and identity in the Island Pacific: A critique. Pacific Viewpoint, 26(1), 316-326. https://doi.org/10.1111/apv.261016

Loyd, J.M., \& Mountz, A. (2018). Boats, borders and bases: Race, the Cold War and the rise of migration detention in the United States. Oakland: University of California Press. https://doi.org/10.1525/california/9780520287969.001.0001 
Lucas, G. (Executive Producer and Director). (1999). Star Wars: Episode I - The Phantom Menace [Motion Picture]. USA: Lucasfilm.

Lucas, G. (Executive Producer), \& Kershner, I. (Director). (1980) Star Wars: Episode V - The Empire Strikes Back [Motion Picture]. USA: Lucasfilm.

Lunine, J.I., Stevenson, D.J., \& Yung, Y.L. (1983). Ethane ocean on Titan. Science, 222(4629), 1229-1230. https://doi.org/10.1126/science.222.4629.1229

Maddox, S.A., Hartmann, J., Ross, R.A., \& Ressler, K.J. (2019). Deconstructing the Gestalt: Mechanisms of fear, threat, and trauma memory encoding. Neuron, 102(1), 60-74. https://doi.org/10.1016/j.neuron.2019.03.017

Mainwaring, C., \& Cook, M.L. (2019). Immigration detention: An Anglo model. Migration Studies, 7(4), 455-476.

Malatesta, S., \& Schmidt di Friedberg, M. (2017). Environmental policy and climate change vulnerability in the Maldives: From the 'lexicon of risk' to social response to change. Island Studies Journal, 12(1), 53-70. https://doi.org/10.24043/isj.5

Mallick, B., Rahaman, K.R., \& Vogt, J. (2011). Social vulnerability analysis for sustainable disaster mitigation planning in coastal Bangladesh. Disaster Prevention and Management, 20(3), 220-237. https://doi.org/10.1108/09653561111141682

McManus, S. (2011). Hope, fear, and the politics of affective agency. Theory $\&$ Event, 14(4). https://doi.org/10.1353/tae.2011.0060

McNamara, K.E., \& Des Combes, H.J. (2015). Planning for community relocations due to climate change in Fiji. International Journal of Disaster Risk Science, 6, 315-319. https://doi.org/10.1007/s13753-015-0065-2

Morton, N.E., Harris, D.E., Yee, S., \& Lew, R. (1971). Pingelap and Mokil Atolls: Migration. American Journal of Human Genetics, 23(4), 339-349.

Naylor, A., Walker, J.F., \& Suppasri, A. (2018). Suitability of the early warning systems and temporary housing for the elderly population in the immediacy and transitional recovery phase of the 2011 Great East Japan Earthquake and Tsunami. International Journal of Disaster Risk Reduction, 31, 302-310. https://doi.org/10.1016/j.ijdrr.2018.05.022

Nunn, P.D., \& Carson, M. (2015). Collapses of island societies from environmental forcing: Does history hold lessons for the future? Global Environment, 8, 110-133. https://doi.org/10.3197/ge.2015.080106

O'Reilly, K. (2003). When is a tourist? The articulation of tourism and migration in Spain's Costa del Sol. Tourist Studies, 3(3), 301-317. https://doi.org/10.1177/1468797603049661

Oakes, R. (2019). Culture, climate change and mobility decisions in Pacific Small Island Developing States. Population and Environment, 40(4), 480-503. https://doi.org/10.1007/s11111-019-00321-w

Orozco, M., \& Hansing, K. (2015). Remittance recipients and the present and future of micro-entrepreneurship activities in Cuba. In P. Brenner, M.R. Jiménez, J.M. Kirk, \& W.M. LeoGrande (Eds.), A contemporary Cuba reader: The revolution under Raúl Castro (pp. 302-308). New York: Rowman \& Littlefield.

Pattullo, P. (2000). Fire from the mountain. London: Constable and Robinson. 
Perumal, N. (2018). “The place where I live is where I belong”: Community perspectives on climate change and climate-related migration in the Pacific island nation of Vanuatu. Island Studies Journal, 13(1), 45-64. https://doi.org/10.24043/isj.50

Petersen, W. (1958). A general typology of migration. American Sociological Review, 2, 256-266.

Picciotto, R. (2018). The Pacific Islands: New priorities for a new development era. Journal of Asia Pacific Studies, 4(4), 527-555.

Pickles, A.R., \& Tosen, R. (1998). Settlement of reclaimed land for the new Hong Kong International Airport. Proceedings of the Institution of Civil Engineers: Geotechnical Engineering, 131(4), 191-209. https://doi.org/10.1680/igeng.1998.30712

Pieterse, J.N. (2000). Globalization and human integration: We are all migrants. Futures, 32, 385-398. https://doi.org/10.1016/s0016-3287(99)00082-8

Pijpe, J., Voogt, A., Oven, M., Henneman, P., Gaag, K.J., Kayser, M., \& Knijff, P. (2013). Indian ocean crossroads: Human genetic origin and population structure in the Maldives. American Journal of Physical Anthropology, 151(1), 58-67. https://doi.org/10.1002/ajpa.22256

Rankey, E.C. (2011). Nature and stability of atoll island shorelines: Gilbert Island chain, Kiribati, equatorial Pacific. Sedimentology, 58, 1831-1859. https://doi.org/10.1111/j.1365-3091.2011.01241.x

Riffat, S., Powell, R., \& Aydin, D. (2016). Future cities and environmental sustainability. Future Cities and Environment, 2, 1. https://doi.org/10.1186/s40984-016-0014-2

Robinson, K.S. (1996). Blue Mars. New York: Bantam.

Robinson, K.S. (1994). Green Mars. New York: Bantam.

Robinson, K.S. (1993). Red Mars. New York: Bantam.

Russell, M.D. (1996). The Sparrow. New York: Ballantine.

Sankoff, I., \& Hein, D. (2013). Come from Away: A new musical. Milwaukee: Hal Leonard.

Schwebel, M.B. (2018). Climate change perceptions and preparation in the United States territories in the Pacific: American Samoa, Guam, and the Commonwealth of the Northern Mariana Islands. Island Studies Journal, 13(1), 135-148. https://doi.org/10.24043/isj. 57

Shapinsky, P.D. (2014). Lords of the sea: Pirates, violence, and commerce in late Medieval Japan. Ann Arbor: University of Michigan Press. https://doi.org/10.3998/mpub.9340182

Shurer, O. (Producer), Clements, R. (Director), Musker, J. (Director), Hall, D. (CoDirector), \& Williams, C. (Co-Director). (2006). Moana [Motion Picture]. USA: Walt Disney.

Sims, H., \& Vogelmann, K. (2002). Popular mobilization and disaster management in Cuba. Public Administration and Development, 22, 389-400. https://doi.org/10.1002/pad.236

Snowdon, W., Lawrence, M., Schultz, J., Vivili, P., \& Swinburn, B. (2010). Evidenceinformed process to identify policies that will promote a healthy food environment in the Pacific Islands. Public Health Nutrition, 13(6), 886-892. https://doi.org/10.1017/s136898001000011x

Stacey, N., \& Allison, E.H. (2019). Sea nomads. In T.J. King \& G. Robinson (Eds.), At home on the waves: Human habitation of the sea from the Mesolithic to today (pp. 309-331). Oxford: Berghahn. https://doi.org/10.2307/j.ctv12pns49.21 
Stojanov, R., Duží, B., Kelman, I., Němec, D., \& Procházka, D. (2017). Local perceptions of climate change impacts and migration patterns in Malé, Maldives. The Geographical Journal, 183(4), 370-385. https://doi.org/10.1111/geoj.12177

Storlazzi, C.D., Elias, E.P.L., \& Berkowitz, P. (2015). Many atolls may be uninhabitable within decades due to climate change. Scientific Reports, 5, 14546. https://doi.org/10.1038/srep14546

Stringer, C., \& Galway-Witham, J. (2018). When did modern humans leave Africa? Science, 359(6374), 389-390. https://doi.org/10.1126/science.aas8954

Swift, J. (1726). Gulliver's Travels into several remote nations of the world. London: Benjamin Motte.

Thomas-Hope, E. (1980). Hopes and reality in the West Indian migration to Britain. Oral History, 8(1), 35-42.

United Nations [UN]. (1998). Recommendations on Statistics of International Migration, Revision 1 (Statistical Papers Series M, No. 58, Rev. 1). New York: United Nations, Department of Economic and Social Affairs Statistics Division.

Watts, N., Amann, M., Arnell, N., Ayeb-Karlsson, S., Belesova, K., Berry, H., Bouley, T., Boykoff, M., Byass, P., Cai, W., Campbell-Lendrum, D., Chambers, J., et al. (2018a). The 2018 report of the Lancet Countdown on health and climate change: Shaping the health of nations for centuries to come. The Lancet, 392(10163), 2479-2514. https://doi.org/10.1016/s0140-6736(18)32594-7

Watts, N., Amann, M., Ayeb-Karlsson, S., Belesova, K., Bouley, T., Boykoff, M., Byass, P., Cai, W., Campbell-Lendrum, D., Chambers, J., Cox, P.M., Daly, M., Dasandi, N., et al. (2018b). The Lancet Countdown on health and climate change: From 25 years of inaction to a global transformation for public health. The Lancet, 391(10120), 581-630. https://doi.org/10.1016/S0140-6736(17)32464-9

Woodward, C. (2008). The republic of pirates: Being the true and surprising story of the Caribbean pirates and the man who brought them down. New York: Harcourt. 